\title{
Gender Performativities in the Quest for Healing, Salvation and Prosperity in An African Pentecostal Church
}

\author{
Ama Boatemaa Appiah-Kubi \\ Center for International Studies, Ohio University, Athens, Ohio \\ Andy Ofori-Birikorang \\ Department of Communication and Media Studies, University of Education, Winneba
}

\begin{abstract}
This paper investigates the performances members of the Moments of Glory Prayer Army (MOGPA), a Pentecostal church in Ghana, display at meetings and how such performances are gendered. Using gender performativity theory and ethnographic design anchored on participant observations, interviews and focus group discussions, the paper reveals that members displayed gendered performances during MOGPA meetings through the frames of prayer, exorcism, testimonies and oblation. However, there were also instances during which individuals engaged in performances that seemed to subvert the normal gender roles regularly subscribed to and acknowledged by society. The study concludes that the performances displayed by social actors at MOGPA meetings were highly gendered and, subsequently, reinforces the gender roles and performances in the church in particular and the society in general.
\end{abstract}

Keywords: Social construction, Gender Performativity, Gender roles, Religion, Christianity, Pentecostalism, ethnography

DOI: $10.7176 / \mathrm{JPCR} / 52-02$

Publication date: February $28^{\text {th }} 2021$

\section{Introduction}

Religion has become a very important and permanent component of human life and clearly remains a vital force in the world today (Grim, 2014).With numerous religious traditions worldwide and practiced by many people, religion sets the tone, liberates and regulates the lives of people into becoming better persons within the society if they conform to societal rules and roles (Durkheim, 1954; Geertz, 1966). Scholars, however, have argued that religion discriminates and divides, giving power to some to the disadvantage of others. Emphasizing the issue of gender in religion as a discriminatory factory, Messner (2002) indicates that religion is a core institution that constantly adheres to traditional gender ideologies. It structures and shapes the everyday life experiences of men and women through gendered religious schemas (Leamaster \& Subramaniam, 2015).

Gender is embedded in every aspect of our daily interactions. This is due to the fact that society constructs and determines the attitude and behavior of people based on their biological make-up (Berkowitz, 2006). Nonetheless, gender is not inherent, rather institutions and systems, like religion, within the society have been known to reinforce and perpetrate gendered practices and performances. As a matter of fact, religious sects provide the platform for gendered performances to be enacted (Sallee \& Harris, 2011).

Ghana, for years, has been characterized as religious country (Asare, 2013), specifically Christiandominated with about $71.2 \%$ of its population being followers of Christ. Undeniably, religion has become the underlining principle governing and giving meaning to the lives of people to the point that Ghanaian culture thrives on religion (Jnr., 2013). According to Bawa, (2017), most Christian religious denominations in Ghana are female-dominated with more women than men identified as Christians according to national census (73.4 and $68.8 \%$ respectively). However, recent developments have caused major change in patronage leading to equal patronage by both genders. In religious sects are found both men and women patrons seeking answers to their everyday problems. The ordinary Ghanaian believes in a supernatural deity responsible for the individual's progress and which at all times fight against people's progress, making it incumbent and prudent to also stand against these forces by associating oneself with a religious body (Asare, 2013) which is believed to hold the antidote to spiritually-induced retrogression in life.

Although a recent study from the WIN-Gallup International 'Religion and Atheism Index' in 2013 found Ghana to be the most religious country in the world with $96 \%$ of the population being religious, it has been argued that various inimical socio-religious and cultural practices give inkling to gender inequality and female subservience in the Ghanaian societies (Bawa, 2017). A critical reflection on this reveals that religious sects have transformed from being female dominated to becoming all inclusive and this has informed the lives of Ghanaians and, in addition, has created a platform for both men and women to find meaning to their lives. This, therefore, calls for an analysis of the reactions and performances that transpire within these sects; how gendered the performances are; and, how religion provides the platform for the gendered activities to be carried out. It is also important to identify the performances of women and men in the any religious grouping, especially a sect that 
has high level of female visibility but continue slide under male (Bawa, 2017). This study, therefore, was conducted on Moments of Glory Prayer Army (MOGPA) a non-denominational prayer ministry based in Kumasi, Ghana with an average patronage of about 10,000 people across the globe and committed to the cause of faith, humanity and God. The study focuses on the gendered performances enacted by congregants during prayer meetings.

Few studies exist on gender in relation to religion (Avishai, Jafar \& Rinaldo, 2015). The majority, using more of quantitative survey and mixed method approaches, has centered on the gender roles executed by men and women in churches and how the patriarchal system of religious institutions seek to marginalize one group over the other (Bawa, 2017; Drogus, 1994; Essien \& Ukpong, 2011; Stephenson, 2011; Walter, 1990). Most of the studies were also conducted in the traditional dominant religious sects like the Catholic Church and were also limited to American and European settings (Drogus, 1994; Flere, 2007; Pricket, 2015; Stephenson, 2011; Walter, 1990). This study contends that minimal studies exist specifically on gender performances in religious environments especially in the quest for healing, salvation and prosperity. Again, the gaps in the studies include utilising qualitative approach to study gender and religion. More significantly, this study identifies the performances displayed during MOGPA gatherings and how gendered they are. It also focuses on unveiling the hidden meanings undergirding the performances and how the meeting grounds serve as a space for the enactment of gendered performances.

\section{Theoretical framework Gender as a Performance}

Given that society typically has a set of roles that men and women are expected to perform, theorists of gender performance suggest that gender is not biologically determined but created through social interaction (Sallee \& Harris, 2011). Gender, collectively created through social communications, is neither a set of traits nor a role but a product of social doing and an accomplishment. It materializes through process, performance and social interactions. People come together to produce gender regardless of whether they subscribe to it or not (Berkowitz, 2006; Deutsch, 2007; Sallee \& Harris; West \& Zimmerman, 1987).

Other schools of thoughts, however, are of the view that individuals are not passive recipients of gender as we make choices to either accept or reject them. In essence, gender is learned (Wood, 2013). Gender is expressed and performed conventionally through daily practices including domineering and deferring among others. For that reason, it is through the act of performance that gender norms are defined and seen as natural. Fundamentally, gender does not exist outside of performance and there is no preconceived notion of gender that is based on biological fact or other functionalist conceptions. Rather, gender and how it is perceived are constituted within performances (Lester, 2008). Performing gender appropriately and simultaneously leads to sustenance, reproduction and legitimization of the institutional arrangements that are based on sex category. However, if individuals fail to perform gender appropriately, they may be called to account for how such individuals enact character, motives, and predispositions.

\section{Performativity Theory}

Simone de Beauvoir (1974, p.89) claims, "One is not born, but rather, becomes a woman." Thus, gender is in no way a fixed identity, rather an identity tenuously constructed in time and instituted through recurring performances (Butler, 1988). According to Performativity theorists, humans construct identities including gender through performances or expressions. Gender which is socially and collectively constructed comes to being only as it is expressed and performed. Hence, it is the performance that is called gender (Butler, 1990; Wood, 2013). Butler (1990) further, adds that there is no preconceived notion of gender that is based on biological facts or entirely feminine or masculine. However, when people perform feminine or masculine traits, they are rather creating and defining their gender regardless of their sex. Similarly, gender is neither passively scripted on the body nor is it determined by nature. Gender is what is put on, invariably, under constraints, daily and incessantly, within a highly rigid regulatory cultural frame that congeals over time to produce the appearance of gaining substance- of a natural sort of being. Gender is a doing (Butler, 1999) signifying that without doing and without the action of performance, there is no gender. Therefore, gender is inextricably linked with sexuality and to that extent becomes performative. Gender is staged in our daily lives and practices through performance. We express or perform conventional gender through every day practices such as dominating or deferring in conversations and offering solutions and judgments. Conversely, we resist conventional views of gender if we act in ways inconsistent with social prescriptions of gender (Wood, 2013). And so, performance theorists assert that all persons perform gender even though it may be done unconsciously. As a result, gender is something we become, not something we inherently are; it is a performance (Butler, 1990).

These performances, however, are repetitions in ongoing social and cultural processes and their actual outcomes are restricted and contextualized based on the socio-cultural norms. The act that one does and performs, is, in a sense, an act that has been going on before one arrived on the scene. It is an act which has been rehearsed 
just as a script of an actor and which requires individual to choreograph in order to actualize and reproduce it as reality (Butler, 1990). The performances take shape within the confines of already existing framework or directives. Performances are hence regulated by clearly punitive and stipulated social conventions so that an unacceptable gender performance sets in motion a social reprisal. On the other hand, conformed performances provide the legitimization of gender identity (Butler, 1988; 1999). It is important to note that performativity includes a wide range of behaviors in the course of one's lifetime (Butler, 1990). These performances are not solo in operations but collaborative. This is because whichever way it is being expressed, it is done in a context of social meanings that outstrip individual experiences (Wood, 2013).

\section{Religion, Christianity and Pentecostalism in Ghana}

As a result of social transformations, religion has emerged as a crucial and permanent component of human life and a vital force in the world as it is practiced and experienced by many people in the 21 st century. It socially transforms people and gives meaning to their lives on the basis of a supernatural being (Grim, 2014; McCullough \& Carter, 2013; McCullough \& Willoughby, 2009; Stowers, 2007; Sulmasy, 2002; Tylor, 1981: Vanderstraeten, 2016). For many Africans and Ghanaians, in particular, religion greatly shapes individuals worldview and participation in social life (Mbiti, 1969). Ghanaians are religiously diverse and ingrained in religious beliefs and practices (Acquah, 2011; Asare, 2013). However, Christianity (71.2\%) dominates the religious landscape relative to membership and expansion (Asare, 2013). With the claim to have the power to meet the spiritual and material needs of individuals that might not be provided by other religions or existing Christian churches, various brands of Christianity have emerged in Ghana. Paul Gifford discusses four key features of the new Christianity, namely: success; deliverance services; extensive use of the mass media to disseminate messages; and the role of testimonies (2005). With this new brand of Christianity, prosperity is the ultimate goal and its failure to manifest becomes attributable to demons or other malevolent spiritual forces with a consequential requisition of some spiritual Christian faith-based deliverance from such malevolent powers (Ngong, 2006). Healing is part of prosperity and wellbeing. However, churches located within the new brand of Christianity do not stress healing; their interpretation of prosperity is strictly material (Ngong, 2006). It is important to establish that such churches are so prosperity-oriented that the theme of prosperity becomes reflective in their names (Victory Bible Church, Winners Chapel). Again, the major themes of sermons and testimonies centre on success, progress, prosperity, financial breakthrough, victory. The dominant theological rendition hinges on the teaching and preaching of success, miraculous healing and wealth (Asare, 2013; Gifford, 2005; Ngong, 2006). This new rendition of Christianity is an embodiment of Pentecostal movement (Ngong, 2006). The churches have given Christianity a new outlook that is expressive, liberating, and appeals to the cultural needs of the African convert (Amanor, 2004). One (1) in six (6) Ghanaians identify as a member of the Pentecostal or Charismatic church (Adjei, 2015). The new brand of Pentecostal churches, which this study focuses on, espouses specific doctrines that distinguish them from other Christian groups. Members believe they constitute a special people of God who have had salvation and all other doomed to perdition. Their premium is baptism of the Holy Spirit, external manifestation of speaking in tongues, faith-based healing (deliverance) and preaching in accordance with prosperity gospel. This is both a spiritual and social marker that sets members apart as God's elected people (Anderson, 2005; Ukah, 2007). It promises individuals a comprehensive solution to all their worries on condition that they become born again and give generously to the religious leader in exchange for material and spiritual blessings expected to manifest in the form of healing, wealth, abundance, success and earthly promotion. The healing is conceived as a total restoration of abundant health bestowed on a believer by virtue of the death of Jesus Christ on the Cross. Healing is not only curative but extends to other situations of morbidity or disability be it physical, material, mental, financial or spiritual (Hunt, 2000). Significantly, pastors of these new churches believe they have been anointed by God to bring physical and spirituall healing to their followers (Ukah, 2007). Therefore, some studies do contend that with the advent and proliferation of Christian fundamentalist or Pentecostal churches, prayer houses and healing temples have mushroomed in many parts of Ghana.

\section{Methodology}

This paper is a qualitative study that aims at identifying performances that are displayed in the quest for healing, salvation and prosperity in an African Pentecostal church, MOGPA. The study further hinges on ethnography which studies the shared patterns of behaviors, language and actions of an intact cultural group in a natural setting over a prolonged period of time. Data were collected using ethnographic and naturalistic methods such as observation, interviews and focus group discussion (Creswell, 2013; Halai, 2006; Hancock, 2002). Observational data were collected over a period of fifteen months using in-depth interviews and focus group discussions conducted with 24 informants. The ethnographic study afforded us the opportunity to immerse ourselves in a purposively-sampled social setting at (MOGPA) and observing and asking questions about the manner in which the people interact, collaborate and communicate (Daymon \& Holloway, 2011). 
The findings of this study are in two-folds: the first part focuses on the performances displayed in MOGPA and the second is focused on how the performances are gendered. Then we proceed to provide conclusion based on our theoretical consideration. We sampled MOGPA because it is the leading prayer camp in Ghana (Adomomline.com, 2017). To retain depth and richness of the data, we also purposively sampled 24 informants who understood the phenomenon under study and were best and willing to provide information by virtue of their experience with the church (Bernard, 2002). Regular visits were made to MOGPA to gain insights into their social practices and performances which under normal circumstances could not be gathered by an outsider. We attended all meeting sessions at the various meeting sites at Abrankese, Cultural Center and the MOGPA House at Adum, Kumasi. We immersed ourselves fully in the way of life of the members, observing keenly all the activities and performances that were displayed. We carried with us palm-sized note pads with which we took field notes and recorded observed behavior and actions of the social actors and other events as they unfolded. The notes taken were later transferred into a bigger log book which we termed as our ethnographic field notebooks (each of us carried a field notebook). In situations where notes could not be readily taken, we used our cell phones to do the recordings. We made 68 ethnographic visits to the site.

Interviews and focus group discussions were also conducted to elicit views and opinions from the participants in order to gain insight and understanding of the participant's perspectives and experiences that could not be observed effectively by other means. We conducted the interviews from the emic and etic perspectives and each interview session lasted 5 to 15 minutes.

Two focus groups were formed comprising seven members each: Four (4) men and three (3) women for the first group and four (4) women and three (3) men for the second group. The focus group discussions gave us a wider reach to seek divergent views from participants on the research questions. We moderated the discussion. Most of the interviews were conducted in Asante Twi (one of the widely spoken dialects in Ghana) and later transcribed and translated with the help of a professional academic translator. Other interviews were, however, done in English language with informants who could speak and understand it.

The data collected were closely and carefully assembled and prepared. Through a careful engagement and examination, patterns and themes were drawn from the data collected (Braun \& Clarke, 2006). This was done in order to have a clear view, description and understanding of the issues into greater detail (Flick, 2013). After having a full grasp of the issues in the data, certain dominant themes emerged following the inductive form of thematic analysis. The analysis of the research questions revealed themes such as prayers, exorcism, testimony, oblation and subversion. These themes were analysed using concepts and theories to draw meanings and responses from the informants. Direct quotations were also used to support interpretations and discussions.

\section{Findings and Discussion}

This paper sought to present a detailed description of data collected from twenty-four informants (24) as well as participant observation to identify the performances displayed during MOGPA meetings and how gendered they are. For easy analysis and interpretation, the data derived was simplified into several thematic units. Each theme was thoroughly described and critically analyzed using the theory of gender and performativity and other concepts that emerged from the related literature. As part of answering the research questions, we inquired into demographic information relating to sex, age range, educational level, ethnic affiliation and professional background of the participants. Out of the 24 informants, twelve (12) were females whereas twelve (12) were males. Three (3) participants were above fifty (50) years, eight (8) were between thirty (30) and forty (40) years, twelve (12) were between twenty (20) and twenty-nine (29), while one (1) was eighteen years (18). Also, eight (8) participants had their educational level up to the tertiary level, five (5) had theirs up to the Senior High School level, seven (7) had their education up to Junior High School level, whereas four (4) had no form of education at all. Again, in terms of ethnicity and origin, fifteen (15) of the participants were Akan; three (3) were $\mathrm{Ga}$; three (3) were Dagartis; two (2) were Ewe; and, one (1) was a Farafara. Finally, fifteen (15) of the informants were employed whereas nine (9) were unemployed.

The demographics point out that though the numbers under the various demographical categories vary, the informants that participated in the research study cut across all the categories (sex, age, educational level and ethnic affiliation). The demographics also indicated that though the age range of the informants cut across, most of them fell within the ages of twenty (20) and forty (40) indicating that the young patronise the sect more than any other age group. Due to adherence to anonymity and confidentiality, informants were represented with alphanumeric codes such as 'Informant1'. Before delving into the detail responses to this question, we first provide a brief description of the site from where the study was conducted.

\section{The Site}

Moments of Glory Prayer Army (MOGPA) is located in Kumasi, Ghana. It has three main meeting premises: Abrankese (a town about $25 \mathrm{~km}$ away from Kumasi); MOGPA House; and, the MOGPA meeting centre at the Kumasi Cultural Centre. These meeting points are each situated a few meters away from the main street at the 
respective locations. The premises are always decorated with purple, mauve and white colors and demarcated into sections. They grounds of meeting are beautifully draped in MOGPA paraphernalia and frequently jampacked with people from diverse background. During each session, a section of the ground is allocated to the General Overseer and his pastoral team and the other section allocated to the congregants. Barriers have been created between the sections to prevent members, especially those not within the executive body, from gaining entry to the segment that houses the General Overseer and his train. The General Overseer is highly guarded by ushers and access is strictly by permission. Boxes coated in the MOGPA colours and embossed with the MOGPA logo are located at vantage points for 'seed sowing' during gatherings at Abrankese and the Cultural Centre (Apatakssec Ase).

The atmosphere at the premises is always filled with gladness, bliss and further hallowed with an aura of comfort and relief. The venues are always filled with melodious tunes of praises and worship songs, as people sing and dance to the glory of God as a way of expressing their appreciation and joy. Usually, most of the congregants arrive approximately three (3) hours early to secure comfortable seats and also to get prepared spiritually before the commencement of each meeting and before the arrival of the General Overseer. It is worthy to note that the General Overseer constantly walks in flanked by his pastoral team (junior pastors) and, as expected, welcomed with applause, screams and standing ovation from the congregants.

The MOGPA grounds are not only for religious purposes, the locations have also been turned into places of commerce with the sale of different products, delicacies, goods such as fizzy drinks, pastries, fufu, noodles, and other non-edible products.

\section{Display of Gendered Performances}

The attempt to identify the performances present in the quest for healing, salvation and prosperity at MOGPA was guided by some concepts drawn from literature as well as Butler's performativity theory that establishes that gender is a socially constructed category created during gendered performances. In responding to the question on identifying the performances displayed during MOGPA meetings and how gendered they are, four (4) main themes came up. These are prayer, exorcism, testimonies, and oblation.

\section{Prayer}

One key performance observed during the study and which was constantly carried out was Prayer which we operationalise as an act of communicating to God, a moment of pouring out one's heart in humility and supplication for a request or a wish so needed. Undeniably, MOGPA was the perfect grounds for these social actors to pray. Throughout the sixty-eight-day visit to MOGPA, there was not a single meeting session held without an act of prayer. Prayer started the very moment the congregants got to the meeting grounds even before the arrival of the pastor and it ran through the entire service. The social actors shared a common belief of a supernatural entity (God) at MOGPA who listens to their cries and pleas. To them, MOGPA is a place of breakthroughs and the latter is possible only through prayers. This dovetails into the assertion made by Ngong (2006) that adherents of the new Christianity of which African Pentecostal churches fall under focus particularly on the subject of God and prayer which ultimately is also concerned with the promotion of the wellbeing of its members. Whereas usually during prayer sessions some leapt to their feet in tears, others stood, clapped their hands, and screamed to God with a voice of triumph. During one of our visits, we were greeted with a scene that put us in a state of awe. We saw people rolling on the floor from one end to the other in frenzied motion while others lifted-up their hands in the air enthusiastically and dug up sand from the ground on which the Pastor had earlier walked,. We came across others leaning against the altar with photographs of their relatives praying and shedding tears over such images. The social actors got so engulfed in the prayers that sometimes it seemed as if they had lost their sense of self in the process.

Just as Gifford (2005) avers that churches under the New Christianity are so prosperity-oriented that the gospel of success even reflects in their names and the key words of their sermons, testimonies, and literature, most of the prayer topics centered on issues of marriage, fruit of the womb, financial breakthrough, acquisition of passports and visas, and employment.

In almost all these prayer topics too, the lack of prosperity connected to the work of the devil. In one of the prayer sessions, for instance, the head pastor charged the congregation to be faithful He said "use your prayers as a weapon to triumph over the devil and principalities..." and this triggered the zeal and energy in the congregants to pray. They prayed stamping their feet and speaking in loud voices subjecting the devil under the feet of the Lord. Often, they used a very common expression known to them all "by fire, die" to castigate and annihilate the devil during prayer. It is important to establish that most of the prayer topics initiated by the Head Pastor began with the phrase, "Any evil power, working against my..." and ended with another "die by, fire". The alignment of prayer topics to that of evil power brings into focus the conviction that the new Christianity (African Pentecostal Churches) focuses more on the realms of demons, spirits, and witches and for that matter attribute societal problems such as unemployment, barrenness, poverty, sickness and the likes as having roots in the spirit 
world (Ngong, 2006). Indeed, the social actors had been indoctrinated into believing that the world is full of evil forces, therefore, they must at all times rise in prayer against these forces. Clearly, members of MOGPA have been coached to discard negativity as stated by Ngong (2006).

Aside this, the prayer sessions were also mixed with a lot of prophetic declarations and this elicited a lot of excited responses from the social actors. They usually shouted, "I receive it" or "Amen". This resonates with what Paloma (2001) indicates, that prophecy is an integral part of Pentecostalism beliefs and practices. The principles of Pentecostalism, therefore, are constituted in a worldview that not only makes room for the prophetic but one in which the prophetic is central.

\section{Prayer as a Gendered Performance}

The prayer sessions as well as the pronouncement of prophetic declarations were mostly led by the head Pastor, with the congregants responding accordingly to them. The responses, reactions and mannerisms of the social actors however, differed depending on the particular prayer point given as well as the prophetic declaration. Prayer topics that centered on marriage and fruit of the womb had a lot of women responding with more urgency and passion as compared to the men. The attitudes of the women towards prayer topics on marriage and fruit of the womb clearly showed that they were particularly in need of such gifts. In one instance, we were amazed to have observed one of the social actors who was a woman and who sat right beside one of us, jump from her seat while screaming "I receive it, I receive I receive it" after which she started praying, moving her hands up and down, left to right until a prophetic declaration of the fruit of the womb (conception) was made upon her by the man of God. Concurrently, another woman who was just some meters away, also had one of her hands raised up, the other on her stomach and all she continuously said was, "Amen, Amen" for about two minutes. In an attempt to find out the reason behind that behaviour, this was what one informant said,

...Conception erm, you know, is with women. Erm, women are to conceive.

Men are not meant to conceive and so definitely when a prayer topic is raised concerning conception, the women definitely will respond more than men...

(Informant, 1)

Another also said,

...a lot of women go in there because of marriage, because of fruit of the

womb, that is what I believe. Because they feel that, in the society, if you are a woman at certain age or class you need to get married and when you get married too, no matter the situation whether the fault is from the man or not, people believe as a woman you have to give birth... (Informant 4)

The rationalization for this indicates that the attitude and responses of women towards fruit of the womb and marriage was due to the fact that Ghanaian society places much premium on marriage and childbirth for women. There is so much expected of women when it comes to issues of childbirth and marriage to that point where in the everyday life of an African or Ghanaian woman, marriage and childbirth become the ultimate life goals. Women have become so accustomed to this idea that they live by it all the time. This adds up to Inglehart and Norris' (2003) assertion that societies emphasize childbearing and child rearing as the central goal of any woman. Marriage is therefore seen as the most important function in life and the greatest source of satisfaction and status of every woman. Also, Adinkrah (2004) reinforces this when he establishes that in the Ghanaian traditional society, women are expected to take care of the home by nurturing and reproducing.

To satisfy our curiosity, we asked one of our informants to discuss with us the relevance of child bearing to her social life,

I am a woman. I want babies. I love babies. I don't wish to be barren because the Bible has said that the barren doesn't live in the house of the Lord... (FGD1, Informant 1)

This is in relation to the conviction that gender division of labour is common in our daily lives; is deeply embedded in our institutions, actions, beliefs, and desires; and, that it appears to be completely natural to the extent that for most people it cannot be challenged. The rationalisation also hinges on the idea that religious sects use their beliefs and doctrines to regulate the lives of their adherents based on their biological make up (Eckert \& McConnell-Ginet, 2013; Leamaster \&Subramaniam, 2016; Lober, 2000). More so, judging from this rationalisation, Grant (2000) and Ingersoll (2003) are right to have acknowledged that when individuals are socialized in the church, they are taught traditional gender roles, and in order to fully live out their faith, are expected to subscribe to and fulfill these roles by acting in ways that are deemed appropriate for their gender.

On the part of the men, they were magnetised, receptive to and interested in prayer topics and prophetic declarations on economic empowerment, job opportunities, financial break through and foreign travels in search of greener pastures. Although their number was proportionally low as compared to that of the women, they were able to respond loudly to issues on these prayer topics and prophetic declarations. Again, their expressions and enthusiasm towards issues in tune with the aforementioned prayer topics and prophetic declarations depicted the vitality and impact such prayer points and declarations had on them. Showing how important such prayer topic was to him, one of the social actors, during one of our visits when the man of God initiated a prayer topic said, 
“Any evil power, working against my financial breakthrough by fire die, die," Probing further to find out why the men were more interested in this, some of our informants stated that prayer topics on employment, financial breakthrough and the like were embedded in masculinities and became more attractive to men because they are expected to take care of themselves as well as their family. Therefore, in their everyday life they tend to look for means to secure themselves financially and economically. Having this intention in mind, the men respond quickly and passionately to such prayer topics, reaffirming Adjei (2014) and Braimah's (2015) assertion that social constructions influence men to behave in ways that confirm the stereotype of masculinity (aggressive, independent, authoritative and controlling) and this affects their perceptions and actions. One of our informants in the interview stated,

If a man wants to marry, without money he cannot...that is why men respond to prayer topics on these issues more than we the ladies. (Informant, 6)

Another informant also said:

...men believe that they are the heads so if I'm not well employed ahh, I cannot take good care of the family. If, erm (pause) I claim I'm the husband, right, I need to take lead in most of the economical or the financial aspects of the family...most of the men come here with that intention. (Informant, 4)

These statements buttress the declaration that males are socialized into secular ideals of accomplishment and are supposed to be independent, take primary responsibility of earning income and be economically strong (Adinkrah, 2004; Jurkovic \& Walker, 2006; Pollack, 2000; Sullins, 2006). For that reason, most of the social actors went to MOGPA in search of ways to better their lives economically and financially. Deutsch (2007) avows that people act in accordance with what has been prescribed as masculine or feminine behavior by the society and to that extent gender is experienced and constructed differently in social and geographical locations, with ethnic, racial and class identifications serving to modify such influence (Woodhead, 2007). From our observations, we recognized that some of the social actors acted contrary to what society had prescribed. Some of our informants were of the view that, sometimes they had to take certain actions because of their current situation and the environment in which they found themselves. They indicated that MOGPA provided the grounds for them to freely and fully present themselves and participate in all activities without any restrictions or intimidation. We noticed during our observations that some of the social actors (men) when it got to the topic of fruit of the womb, acted as proxies for their wives and responded to the call with some level of pride in their faces. In one instance, the man of God called for those in need of fruit of the womb to come to the front of the altar and a significant number of men heeded. Upon enquiry, he said he had to stand in for his wife because she was not available at that moment. Going further, he said, his wife would not get pregnant alone but with him so there was the need for him to take some of the initiatives since they are in it together. This confirms that gender continues to be transformed as our social life changes (Eckert \& McConnell-Ginet, 2013).

More so, Jurkovic and Walker (2006) have established that men usually do not have to talk about their problems to anyone out of fear or embarrassment of being seen as weak. Nonetheless, some of the social actors went contrary by announcing their need to the entire world hence affirming that though gender remains the basis on which sexuality is structured, we live in a world in which gender relations themselves are constantly evolving and being transformed (Ocha, 2013).

Again, during the prayer sessions, whereas the women exhibited a lot of physicality, the men were sober and timid. The women clapped their hands, spoke loudly, held their waists, moved away from their seats, moved up and down and shook their heads back and front. The men, however, stood in front of their chairs, muttered, and quaked. One of us happened to be seated beside a lady during one of the prayer sessions and in a stern and motherly tone, she requested us to be serious with the prayers. According to her, we were being too solemn and slow with the prayer. She expected that we added a little bit of energy to it because the prayer session was a time to claim what we needed from God in all seriousness. She further said we should be serious with the prayer because the ground upon which we stood was not for trivialities. She did not even end and we were up praying as expected. For this particular social actor, the environment and the situation in which we found ourselves called for a different kind of attitude and behavior. To her, our style of prayer was weak. Therefore, to show some level of seriousness, we needed to energize it by adding a bit of physical strength through our actions and words. These reactions validate Chen's (2005) claim that men can behave in ways stereotypically associated with femininity and women may display masculine behaviours when they need to appear strong.

\section{Exorcism}

Exorcism or what has been referred to by Paul Gifford as deliverance is one of the key characteristics of African Pentecostal Churches. These churches believe that success which comes in the form of healing and other material gains is the right of the believer, therefore, whenever it fails to materialise it is said to have been blocked by demons or other malevolent spiritual forces and thus requires deliverance from such forces (Ngong, 2006). Within MOGPA therefore, exorcism seems to be one of the major activity or performances carried out. 
Having at the back of their (social actors) minds that they would be delivered from the malicious one and regain their true god-ordained identity during this period, the social actors endlessly waited in anticipation of the period of exorcism. This performance took place about two to three hours after the commencement of each meeting session. The process, each time, involved a call from the Head Pastor on the congregants suffering demonic afflictions in the form of diseases, bareness, unemployment, and others to come to the altar. These calls saw a lot of people ran to the front of the altar while some others stood in front their seats in prayer mood. Simultaneously, the Head Pastor and his team (junior pastors who were male) positioned themselves around the social actors in front of the altar. The ushers on the other hand did same but then again, packed all chairs within the circles of where those to be exorcised stood. Around the congregants were male ushers with their hands held together to form a semicircle that served to barricade those being exorcised from falling. Interestingly, the social actors held the belief that a struggle always ensued between the devil being exorcised and the body in which the devil in the form of a demon had taken possession. The brute strength displayed by the possessed member was a manifestation of the demon's refusal to surrender to the exorcist. According to our informants, the strength wielded causes the body of the one being exorcised to behave in ways that require that ushers present supported them from dangerously falling and hurting themselves as well as others. The ushers and the junior pastors also held waist wrappers (clothes) and a bowl of anointing oil during this period. The wrappers were meant to cover the waist of the women whereas the bowl of anointing oil was meant for the Pastor to use for the exorcism. Although, those in front happened to be at the center or the key parties to be exorcised, the other social actors equally benefited and shared in the exorcism process.

Bawa (2017) postulates that the fruitful recruitment of members into African Pentecostal churches, to a large extent, is dependent on the ability of the head pastor to intercede on behalf of members to resolve various health, socioeconomic, and cultural problems. Likewise, in MOGPA, the head Pastor with the assistance of his pastoral team always used the period of exorcism to intercede on behalf of members and also resolve their numerous problems. He did this by continuously leading the exorcism process. Captivatingly, his demeanor during the performance of the exorcism came with some form of potency and triumph. Most of the time, he shrieked and sang in a deep baritone voice which sometimes caused him to lose his voice. Sometimes, sweats gathered to break away into sweat, trail down his body and soaked his outfit because of this conduct. Depending on the direction of the Holy Spirit, as our informants indicated, the Pastor either placed his hands, already dipped in the bowl of the anointing oil either on the forehead or the stomach of the exorcised. These actions were accompanied by him either blowing air through the microphone onto the congregants to be exorcised amidst expressions like "Come out in Jesus name" or "Release by the blood of Jesus" or "Receive your healing in the name of Jesus".

\section{Exorcism as a Gendered Performance}

The literature on gender suggests that women are inherently weak, fragile and have emotions whereas men are expected to be really tough, strong, stoic and should not, in anyway, show emotions or weakness (Adinkrah, 2004; Karklina, 2015; Pollack, 2000). Repeatedly, these prescriptions and behaviour expectations were manifested during the exorcism sessions in MOGPA. As said earlier in this work, the exorcism process was always led by the Head Pastor. During these periods, he laid his hands on the social actors or stood a few meters away from them to perform the action. We noticed that the touch of the man of God was met with multiple and diverse reactions from the social actors and these manifestations differed according to their gender. Whereas the men stood firm and seemingly resisted falling during the exorcism process, the women on the other hand, without any sign of difficulty, fell with the slightest touch. The fall of the women also came with a lot of screaming, whirling, ear piercing verbal utterances and sometimes shedding of tears. During some of our visits for instance, in the process of falling, some of the women screamed and passed certain comments like "Me mmano nware, Maame Joo wadi scn, me mma no nware oh tom" (I won't allow her to marry, how old is Maame Joe? I won't allow her to marry); mmarima w'sтu beware wo dec bebiree nanso disappointment" (I won't allow her to marry. There are a lot of men who want to marry you but face disappointment). These utterances go further to validate the claim that marriage is a key factor in the lives of women as espoused by some scholars. To our informants, these manifestations were because of the nature and embodiment of the social actors based on their sex. The men hardly fell because naturally men are to be very tough whereas women exhibited such performance due to the fact that they are weak and easily give in to emotions. During one of my focus group discussions, an informant asserted,

Women are very soft and emotional, therefore wherever they find themselves,

they tend to scream and cry. The men are strong so they are able to withhold

their emotions unlike the women (FGD1, Informant 4).

Another informant concurred with the above assertion by stating that,

Women are soft, women are very soft. Erm, when it comes to heart issues women are very soft. Women, erm, believe things easily but men find it 
difficult to believe things easily...it takes time for men to believe something.

When it comes to heart issues, women are very soft... (FGD1, Informant 6)

The above excerpts support the evidence from the literature that women are deemed physically weaker, emotional and softer whereas men are strong, tough and have emotional control as argued by Adinkrah (2004) and Bagheri (2012).The ability of the men to withstand the fall also affirms the notion that men have been socialized to bear both physical and emotional pain (Ampofo \& Boateng, 2007). Further, although, both male and female ushers performed their tasks virtually within the same hours, we observed that the performances varied widely. Anytime these manifestations were ongoing, there were men (ushers) numbering about two to three who flanked the social actors being exorcised to prevent them from falling while the women ushers held pieces of wrappers (clothes) to be used to wrap around the waist of the women undergoing exorcism just in case they should fall and reveal some form of nudity. At some point, the women had to multitask by wiping the floor off liquids such as oil stains and pukes from congregants being exorcised. From the performances, it was obvious that the acts of the men centered more on those that required a lot of physical energy whereas the women focused more on female inclinations. As part of the immersive acts of ethnography, one of us responded to an altar call for those who were suffering from one disease or the other and the very moment she got to the front stage, she found herself being wrapped with a piece of cloth and directly behind her, stood two gentlemen. According to them, the wrapper was to prevent any display of nudity or nakedness should there be a fall. The men behind her, however, were to prevent her from falling. An answer given by an informant when we inquired indicated that some duties in their activities were for the men because it required a lot of physical energy and strength with particular emphasis on preventing people from falling. An informant averred:

Men have the strength to hold people when they are falling. A woman doing it will require more hands than expected. Sometimes, we all try to help but we end up being hurt on the way because we cannot stand the force and pressure

that comes with it. We just had to stop for the men to do it because they do it with ease... (Informant, 7). Another also indicated:

...Madam, you are aware that some works are not meant for men. We all help but some works are specifically for men and others for women... if you have

observed, we, the men help during the deliverance especially when someone falls. The women can't handle that... (Informant, 2)

Taking it from the assertion that in most societies there are clear patterns of work for men and women both in the household and in the wider community, people are made to believe and act appropriately towards these patterns. The literature indicates that within the African and Ghanaian society, men are socialized into believing that being a man or masculine is to wield strength, being tough and bold. Women on the other hand are made to conform to domestic chores within and outside the home and also made to accept weakness and fragility as part of their biological makeup (Adinkrah, 2004; Sullins, 2006). Our study confirmed this assertion as both men and women acted in similar manner. These social actors saw the task of preventing people from falling solely as the duty of men because naturally they have the strength and ability to offer physical support (Adinkrah, 2004). To them, women do not have the capacity to perform such duty. Similarly, the women, due to their inability to witness the nakedness of their fellow women, were to take charge of covering them up with cloths and at the same time wiping the floor off dirt should there be. According to this social actor, allowing a man to perform such duties would be an insult to his status. This is consistent with the social conviction that women by their inclination are socialized into compatible morals such as care giving as well as performing domestic and less prestigious chores (Signorielli, 1990; Sullins, 2006). It is further supported by the idea that performance of gender can maintain the privileged position of one group while simultaneously marginalizing the other (Bantjes \& Nieuwoudt, 2014).

Deutsch (2007) and Gallup (1990) avow that the attitudes of individuals tend to resonate with traditional gender role expectations and this is because they act in accordance with what has been prescribed as masculine or feminine behavior by the society. This contention, however, is debunked in our study as our findings indicated that the social actors did not at all times follow such prescriptions. For example, sometimes the female ushers single-handedly not only covered other women with wrappers but also took up the role of supporting them from falling. An interaction with some of the women ushers on this role change revealed to us that they needed extra strength to perform that role. To them, it did not matter how tough it appeared for as long as the environment permitted them to do so. An informant declared:

Sometimes, we also help. The men get very busy during the deliverance session and we can't wait for them if the wrapper gets off a person's waist. It wouldn't be appropriate for the people here to see the nakedness of someone. The work is difficult but we are able to do it...

Another also indicated: (Informant, 8)

(Giggles)...Oh! It's true it's not easy but it doesn't matter here. You can do anything provided 
you want to do it (Informant, 9).

Our findings further indicated that the women (social actors) who were exorcised exhibited an unusual strength which called for the hands of more than two men to prevent a fall. As stated earlier, the social actors revealed that the strength possessed is due to the struggle that occurs when the demonic power is losing control over their body. To them, anytime the demonic power refuses to succumb to the power of God, a spiritual struggle that manifests as physical ensues and that causes those being exorcised to act in ways that come with a lot of brawl, convulsions and quaking. Interestingly, sometimes, the force and scuffle displayed by the exorcised appeared so fierce that, in certain instances, the man of God would order the male ushers to step aside until the demon-possessed person calms down.

This finding indicates that although women and men are socialized into behaving in certain distinct ways, the social actors did not at all times exhibit the behavior patterns that had been prescribed for them. Undeniably, the environment in which they found themselves as well the circumstances that surrounded them played a crucial role in effecting this subversive behaviour. The female ushers did not show weakness and fragility as society has prescribed for them, neither were the men always bold, tough and fearless as they are believed. This further proves that at every point in time gender is being created, re-enacted, and amended in specific situations (Berkowitz, 2006). It further sits well with the assertion that gender is experienced and constructed differently, in different social and geographical locations (Sallee \& Harris, 2011; Woodhead, 2007).

\section{Testimonies}

As stated earlier, testimony is a key feature in African Pentecostal churches (Gifford, 2004). It is the act of honouring the Lord by bearing witness to others about his work in your own life. This conviction was made manifest during the study. In MOGPA, testimony played a central part in all meeting sessions as time was allocated purposely for it. Testimonies invigorated and excited the social actors as they were constantly reminded of God's presence and work in their midst. The social actors enjoyed the testimonies with the hope and sense of comfort that their wants and needs would one day be met in the environment they found themselves just as others had experienced in their lives. Sharing of testimonies gave social actors the opportunity to share in the joy of one another through motivational speeches and words of encouragement. In a conversation with some informants, they stated that testimonies are very relevant and so quite often, they ask the Lord to deliver them from afflictions so that they can equally testify to his salvation. Another informant who was the chief usher in MOGPA also stated that testimonies are weapons to overcome the power of the devil and one of God's intentions in saving us is that we will in turn honour him by sharing our testimony with others.

It is worthy to note that there were two testimony sessions during each meeting session. The first occurred right before the commencement of a day's meeting session, when the technical team set up the place while the other social actors await the arrival of the Head Pastor. The second session sometimes came before or after the praises and worship session depending on the nature of the gathering. Whereas the first part comprised testimonies that had been given months earlier, the second part encapsulated the most recent testimonies to be shared. Excerpts from both sessions were televised and projected for viewing by all members on separate TV screens and projectors placed at vantage points at the meeting grounds. The social actors, therefore, always watched, listened and followed consciously and cautiously.

Anytime, there was a call for testimonies, the social actors walked to the front stage in their numbers to testify. Sometimes, to prevent overcrowding and save time, only those whose names had been put down were called upon. The speakers started the testimony with a call on those gathered using the MOGPA greetings, followed by an introduction of themselves, their stories and then ended with an appreciation to the Head Pastor and then to God. Amazingly, the testimonies were shared in exhilaration and sometimes tears. Coupled with sentiments from the crowd the testimony givers lacing their narratives with gestures and comic enactments shared their stories with embellishments. In a particular instance, a bubbly looking woman clad in MOGPA scarf and wrist bands took to the podium to share her testimony. With a reverberating voice, she greeted the teeming congregants, "Ablaze ohhh!" and in a lighthearted and hilarious voice, they also responded "For God ohhhh!" amidst brassy and strident sounds the church's bandsmen. It is important to know that the sharing of testimonies bond members of the church together, as they open up their lives to one another. Significantly, the testimonies were shared by both men and women, old and the young, educated and the uneducated. They also came in different forms including, fruit of the womb, marriage, employment opportunities, financial break through, international travel visa requests and better educational prospects, among others.

\section{Testimony as a Gendered Performance}

The findings of our study indicated that the testimonies shared by the women and the men varied widely in nature. As stated earlier, the testimonies centered on fruit of the womb (conception in marriage), employment opportunities, and financial breakthrough. The study revealed that most of the testimonies given by the women focused primarily on fruit of the womb, safe birth delivery, marriage, protection of family- especially children, 
and healing from diseases. More so, before sharing their testimonies, the women at times gave appellations to God, broke down in tears and even, sometimes, leapt to their feet. These expressions according to some of my informants were indications of gratitude to God and to the Head Pastor. Most importantly, it was a sign of redemption from a place of hopelessness to that of hope. On the contrary, the testimonies of men centered on issues of financial breakthrough, employment opportunities, visa, defrayment of debts and the like. To most of my informants, the prosperity of women lay in their ability to get married, bear children and care for the home. A man's prosperity, however, is to wield some kind of hegemonic power in terms of social and economic might. Going contrary to these, to the informants, would amount to courting punitive actions for the self. Listening to one informant, she avowed:

...if somebody came with the husband, while the woman is receiving fruit of the womb, the man will also be receiving financial breakthrough...she loves giving birth than money. If the woman can't give birth, it might even be the fault of the man but he wouldn't be blamed, ahh! Rather the woman will be blamed... and for a man, it would be very difficult for him to allow a woman to manage his home. I doubt. In case, he doesn't have money and job but the woman has money, the woman wouldn't respect him... (Informant, 3)

In the words of another informant:

Majority of the women here come here because of childbearing that is why they receive that more than anything else. For the men, their main aim for being here is for foreign travel and job breakthrough. You see, they will get money to marry and give birth, when they get the opportunity to travel ... (Informant, 5).

As has been argued, men are socialized into ideals of accomplishment. It is considered manly when a man takes primary responsibility for earning income and being in charge of most important household decisions. In most peasant societies, from Inglehart and Norris' (2003) perspective, a conflict will ensue between the social norms shaping the appropriate division of sex roles and the actual life experiences of women and men particularly if the male loses his ability to act as the major breadwinner of the household. Men, therefore, are supposed to be independent, economically strong and dominating (Adinkrah, 2004; Pollack, 2000).Women, on the other hand are confined to the home (Fleischmann \& Scheible, 2012)). They are made to believe in nurturing, reproduction, marriage and care giving as their sole functions in life. Their sense of fulfillment, therefore, is dependent on their ability to satisfy these or play by them. Excerpts from the above data validate these claims, where social actors displayed the toll these social prescriptions had on them. For these social actors, to be is to be what society tells and not otherwise. In lieu of this, every act they engage in tends to be in accordance with what has been given by society. To be a woman is to be someone with a child to hold on to and to be a man is to be accomplished, financially. During one of the testimony moments, a woman in tears adorned in white cloth and clad in MOGPA scarf and wrist band testified to the greatness of God in her life because she has given birth to child. In her testimony, she said, it had been very difficult for her to give birth after being married for 6 years. She had to endure the pressure and shame from her family all those years. However, after joining MOGPA and having followed the counsel of 'Daddy' (Head pastor), she had been able to put to birth. Even when the doctors and nurses said in her womb lay fibroid and not a fetus, God delivered her from disgrace. Before she ended, a lady who, presumably, was in her 50's screamed saying "MOGPA ba, MOGPA ba, won 'suffer' oh!" meaning a child of MOGPA will not suffer. Such reactions came from a lot of the congregants on different occasions when testimonies were being shared. Sometimes, in unison they joined the person giving the testimony to sing to God and also thank the Head Pastor for the help. This indicated the kind of fulfillment and joy testimonies brought to the lives of the social actors. The men equally had the same experiences when they shared their testimonies.

One interesting thing we observed during the testimony time was that on occasions when the testimonies were shared by a couple, the women only did the talking whereas the men stood behind with their arms folded. Some men, to the informants, lack the power and courage to stand and speak in front of a huge crowd like the one in MOGPA. One informant stated:

When it comes to the testimonies, I know a lot of people. Sometimes, they are a couple but when they are sharing their testimonies, only the woman comes to the front stage, the man doesn't...to me, I think it's because the men are shy. Some of them are shy so only their wives come to the front stage... (FGD2,

Informant 4)

This manifestation of the silence of men during the sharing of testimonies goes to substantiate the claim that men must "keep a stiff upper lip," "not show their feelings," and "act real tough" (Pollack, 2000). Even so, in the traditional Ghanaian society, men are supposed to be assertive, vociferous, bold, self-confident and active. They are also expected to dominate, be in authority, have power and be in leadership positions. Women on the other hand are to be calm, tender and be in the subordinate position of taking decisions from the "Bosses", men (Adinkrah, 2004; Karklina, 2015). In this study, however, this idea has been subverted because in several instances women were rather taking lead roles, making public declarations while the men lay in the shadows of 
the women. Instead of taking the lead role of speaking for the family and dominating, the men rather took the subordinate positions. At this point, it could be deduced that the women had become the 'bosses' and the men 'subordinates'.

Furthermore, per the norms of society, anyone who contradicted the prescriptions of society is tagged as 'barima besia' meaning 'man woman' for men and 'sbaa barima' meaning 'woman man' for women. Nonetheless, in this study we observed that the social actors who went contrary to their accepted prescriptions were rather hailed and cheered.

\section{Oblation}

Of significant importance in the activities of MOGPA was the act of oblation which is the presentation or offering to God. The act of oblation was in two forms, offering and seed sowing. These acts at MOGPA were not mandatory. Nonetheless, the social actors had been made to know and understand the essence of giving onto God. During each service, bowls and boxes were put at vantage points for easy access by the social actors during offering and seed sewing sessions. Even though both acts were performed as and when the social actors deemed fit, that of offering happened predominantly during ministrations by the Pastor and the praises and worship (Vessels of worship) team. Usually, the social actors in performing the act of offering, either ambled solemnly in prayers or briskly in screams of joy and excitement towards the offering bowl.

\section{Oblation as a Gendered Performance}

Existing studies characterise males as intelligent and full of wisdom and tough (Ampofo \& Boateng, 2007). The precepts in such characterisation were substantiated in our findings which indicate that during the act of giving onto the Lord, the women responded easily compared to the men. Interactions from the social actors revealed that patronage of offering was dependent on the effects of a ministration on member. They further revealed that because men are rational thinkers, they do not take in or believe things easily as compared to women. Whereas a man will ponder or deliberate on issues critically before acting, a woman would however, act instantly without having a second thought. To some of them, women are emotional beings and as such act according to their emotions whereas men are rational thinkers.

One informant stated:

...you see, when it comes to heart issues, women are very soft...women are emotional beings and erm, men are more of intellectual beings, ok! Erm, men think through something for a while before they come out with (pause), you know, erm a solution. Ok! or before they come out with anything about that thing. But women, you know because they are emotional eh, erm they do things eh according to their emotions eh. And emotional beings eh respond to things faster. So, whenever there is a song ministration and songs eh induce people ok, whenever, there is a song ministration ok, and erm it induces you know the women. Because they are emotional beings eh, they respond faster eh to the music and thereby erm it turns out that many of them would be giving out money eh. But you see the erm, the men because they are intellectual beings, they would be sitting down there thinking through the song eh before eh it Another also indicated: gets in them... (Informant, 1)

...women are impulse buyers (giggles). Whatever they see as being of more importance to them if they have money, they will acquire or get it. But for men, if they have not planned, no matter the situation, it will be very difficult...Virtually, a woman will go to the grounds with no intention of going to sew a seed but as the person is seated there and her emotions is being carried away, they don't check whether that money is for their erm house keep something, they will just give it out. But for men they give with the intention, they think about whatever that they are giving so they go there only when they feel it's necessary for them to give but women don't consider the necessity of their giving. They consider what their emotions are telling them to do so while they are there, they are enthused with the ministration, they are also motivated by the word being given by Reverend, they feel it's very important for them to give... (Informant, 3)

These perspectives are in consonance with the literature on stereotyping in which women are branded as soft, passive, less intelligent and easily susceptible to things while whereas men are intelligent and rational. It also brings to bear the notion that men are naturally tough and are able to withstand certain things as compared to women (Ampofo \& Boateng, 2007; Karklina, 2015; Sullins, 2006).

Fleischmann and Scheible (2012) assert that traditional gender ideology confines women to the home and limits their opportunities regarding economic activity and range of occupations. Nonetheless, this idea was subverted when our findings found out how the women went beyond the idea of domesticity and demonstrated their economic capacity in terms of seed sowing and offering. As argued, women are limited when it comes to 
economic issue. Nonetheless, from the data excerpted, it is evident how the women freely engaged in seed sowing and offering during MOGPA meeting sessions. More so, the idea of men being bold (Karklina, 2015) was countered in the study. Men never showed their economic might with the fear of not knowing what their offering would bring them.

\section{Conclusion}

These gendered performances can equally be explored through the lens of the performativity theory. The findings of this work validate the claim that gender is a socially constructed category created during gendered performances (Butler, 1990) because the social actors in partaking in the various activities in MOGPA demonstrated and acted in ways that were in synchrony with the societal prescriptions based on their sex. Through the performances of these societal prescriptions they asserted their identity as men and women as argued by Butler (1990).

More so, the data showed that because society requires men and women to act in certain distinct ways, the social actors had become accustomed to such ways of behaving, to the point of such behaviours becoming their reality. The social actors knowing that society has set roles for them acted in ways that would not subject them to punitive actions. The fear of being ridiculed by society should one go contrary to it made it almost impossible to question the authenticity and originality of the prescription. It also brings to bear the idea that gender is staged in our daily lives and daily practices like a performance. It is performed and constructed in situated interactions. Instead of defining who we are intrinsically as people, gender is what we are doing at specific situations. Additionally, the findings also indicate that contradicting gender performance called for some sort of punitive action. Through their performances, members of the sect also indicated how inappropriate it will be to the extent of it having psychological and physical impact should one act contrary to gender prescriptions. This is in consonance with the assertion that gender performances are governed by clearly punitive actions and regulatory social conventions where a wrong gender performativity initiates a set of reprisals (Butler, 1988; 1999). On the contrary, performing it right provides the reassurance that there is an essentialism of gender identity (Butler, 1988). This was exemplified in the current study when the social actors in most of their performances acted appropriately according to the social prescriptions of gender.

Also, the findings indicated that the social actors were not ignorant of their performances relative to what society expects from them. Having full knowledge of what was expected of them and being consciously aware of the sanctions that would come on them should they go against the norms, they behaved in ways that conformed to the prescriptions. So, gender is an act which has been rehearsed much as a script in the hands of an actor, and which requires the actor to reproduce as reality. The participants in this study in some instances also subverted the societal prescriptions through their performances. In spite of these subversions, gender was still being performed (Butler, 1990).

Finally, as Simon de Beauvoir expounds, to be a woman is to have become a woman or to compel the body to conform to a historical idea of woman or to induce the body to become a cultural sign and this is to be done repeatedly (De Beauvoir, 1974). In similar vein, what the social actors demonstrated in their performances was to allow the each individual to be known and regarded as masculine or feminine within the society and to become fully subjected into doing what is expected of them. Logically, they wholeheartedly worked themselves out in fulfillment of those social expectations through such performances in iterative bodily gestures, movements and through other similar enactments.

\section{References}

Acquah, F. (2011). The Impact of African Traditional Religious Beliefs and Cultural Values on Christian-Muslim Relations in Ghana from 1920 through the Present:A Case Study of Nkusukum-Ekumfi-Enyan area of the Central Region (Doctoral Thesis). University of Exeter. Retrieved from https://ore.exeter.ac.uk/repository/bitstream/handle/10036/3473/AcquahF.pdf?sequence=3\&isAllowed=y

Adinkrah, M. (2004). Witchcraft Accusations and Female Homicide Victimization in Contemporary Ghana. Violence Against Women, Vol. 10 No. 4 , pp. 325-356. doi:DOI: 10.1177/1077801204263419

Adjei, E. A. (2014). Gender Role Stereotypes In African Children's Literature (Master's Thesis). University of Ghana, Legon, Accra. from http://ugspace.ug.edu.gh/bitstream/handle/123456789/21199/Gender\%20Role\%20Stereotypes\%20in\%20Af rican $\% 20$ Children $\% \mathrm{E} 2 \% 80 \% 99 \mathrm{~s} \% 20$ Literature $\% 20-\% 202014$.pdf?sequence $=1 \&$ is Allowed $=\mathrm{y}$

Amanor, J. D. (2004). Pentecostalism in Ghana: An African Reformation. Cyberjournal for PentecostalCharismatic Research, Vol.13, pp.1-34.

Ampofo, A. A., \& Boateng, J. (2007). Multiple meanings of manhood among boys in Ghana. From Boys to men: Social constructions of masculinity in contemporary society, 50-74.

Anderson, A. (2005). An Introduction to Pentecostalism: Global Charismatic Christianity. Transformation, $175-$ 185 . 
Asare, K. (2013). Pentecostal-Charismatic Christianity in Video films: Audience Reception and Appropriation in Ghana and the UK (Doctoral Thesis). University of Edinburgh, Edinburgh. Retrieved from https://www.era.lib.ed.ac.uk/bitstream/handle/1842/8903/Asare2013.pdf?sequence=1\&isAllowed=y

Avishai, O., Jafar, A., \& Rinaldo, R. (2015). A Gender Lens on Religion. Gender \& Society, Vol 29(1), 5-25. doi: $10.1177 / 0891243214548920$

Bantjes, J., \& Nieuwoudt, J. (2014). Masculinity and Mayhem: The Performance of Gender in South African Boy's School. Men and Masculinities, Vol. 17(4), 376-395. doi:10.1177/1097184X14539964

Bawa, S. (2017). Christianity, Tradition, and Gender Inequality in Postcolonial Ghana. African Geographical Review, 1-16. doi: 10.1080/19376812.2017.1286245

Berkowitz, D. (2006). Consuming Eroticism: Gender Performances and Presentations in Ponographic Establisments. Journal of Contemporary Ethnography, Vol.35(5), 583-606. doi:10.1177/0891241605285402

Bernard, H. R. (2002). Research Methods in Anthropology: Qualitative and Quantitative Methods (3rd ed.). CA: Alta Mira Press.

Braun, V., \& Clarke, V. (2006). Using thematic analysis in psychology. Qualitative Research in Psychology, Vol.3 (2)(ISSN1478-0887), 77-101.

Butler, J. (1988). Performative Acts and Gender Constitution: An Essay in Phenomenology and Feminist Theory. Theatre Journal, Vol. 40(4), 519-531.

Butler, J. (1990). "Gender Trouble, Feminism Theory and Psychoanalytic Discourse" in Feminism/Postmodernism. (L. Nicholson, Ed.) London: Routledge.

Butler, J. (1999). Gender Trouble: Feminism and the Subversion of Identity. New York: Routledge.

Creswell, J. W. (2013). Qualitative Inquiry and Research Design: Choosing Among Approaches (4th ed.). Los Angeles, CA: Sage Publications.

Daymon, C., \& Holloway, I. (2011). Qualitative Research Method in Public Relations and Marketing Communications (2nd ed.). London: Routledge.

De Beauvoir, S. (1974). The Second Sex. (H. Parshley, Trans.) New York: Vintage, 1974.

Deutsch, F. M. (2007). Undoing Gender. Gender and Society, Vol. 21(1), 106-127.

Drogus, C. A. (1994). Religious Change and Women's Status in Latin America: A Comparison of Catholic Base Communities and Pentecostal Churches (Working Paper). Retrieved from https://kellogg.nd.edu/sites/default/files/old files/documents/205 0.pdf

Durkheim, E. (1954). The Elementary Forms of Religious Life. (J. Swain, Trans.) New York: The Free Press.

Eckert, P., \& McConnell-Ginet, S. (2013). Language and Gender. Cambridge University Press.

Essien, A. M., \& Ukpong, D. P. (2012). Patriachy and Gender Inequality: The Persistence of Religious and Cultural Prejudice in Contemporary AkwaIbom State, Nigeria. International Journal of Social Science and Humanity, Vol. 2(4), 286-289.

Fleischmann, F., \& Scheible, A. J. (2012). Gendering Islamic Religiousity in the Second Generation: Gender Differences in Religious Practices and the Assoication with Gender Ideology among Moroccan and TurkishBelgian Muslims. Gender \& Society, Vol. 27(3), 372-395. doi:10.1177/0891243212467495

Flere, S. (2007). Gender and Relgious Orientation. Social Compass, 54(2), 239-253. doi:10.1177/0037768607077035

Flick, U. (2013). Qualitative Data Analysis. The Sage Handbook of Qualitative Data Analysis.

GallupOrganiation (1990, September/October). April 19-22 survey. American Enterprise. Retrieved from American Enterprise.

Geertz, C. (1966). "Religion as a Cultural System". In M. B. (ed.), Anthropological Approaches to the Study of Religion, (pp. 1-46). London: Tavistock.

Gifford, P. (2005). "A View of Ghana's New Christianity". The Changing Face of Christianity Africa, the West and the World.

Grim, B. J. (2014). Growing religion and growing religious restrictions: A global overview. International Area Studies Review, Vol. 17(2) , 134-145. doi:10.1177/2233865914537054

Grant, B. (2000). The social structure of Christian families: A historical perspective. St. Louis: Chalice Press.

Halai, A. (2006). Ethics in Qualitative Research: Issues and Challenges. EdQual A Research Programme Consortium Implementing Education Quality in Low Income Countries. EdQual Working Paper Number, 4, $1-12$.

Hancock, B. (2002). Trent Focus for Research and Development in Primary Health Care: An Introduction to Qualitative Research. Trent Focus.

Ingersoll, J. (2003). Evangelical Christian women: War stories in the gender battles. New York. New York City: New York University Press. .

Inglehart, R., \& Norris, P. (2003). Rising Tide: Gender Equality and Cultural Change around the World. New York: Cambridge University Press.

Jnr., G. A. (2013). Religion and Morality in Ghana: A Reflection. Global Journal of Arts Humanities and Social 
Sciences, Vol.1(3), 162-170.

Jurkovic, D., \& Walker, G. A. (2006). Examining Masculine Gender-Role Conflict and Stress in Relation to Religious Orientation and Spiritual Well-Being in Australian Men. The Journal of Men's Studies, Vol. 14(1), 27-46.

Kārklina, A. (2015). Measuring Gender Attitudes Among Male Adolescents and Young Men in Accra, Ghana (Research Report). Hart Leadership Program, Duke University. Retrieved from http://gendercentreghana.org/wp-content/uploads/2015/06/HLP-Final-Report-A-Karklina.pdf

Leamaster, R. J., \& Subramaniam, M. (2016). Career and/or Motherhood? Gender and the LDS Church. Sociological Perspectives, Vol. 59(4), 776-797. doi:10.1177/0731121415603852

Lester, J. (2008). Performing Gender in in the Workplace Gender Socialization, Power, and Identity Among Women Faculty Members. Community College Review, Vol. 35(4), 277-305. doi:10.1177/0091552108314756

Lorber, J. (2000). Using gender to undo gender : A feminist degendering movement. Feminist Theory, vol. 1(1), 79-95.

Mbiti, J. S. (1969). African Religions and Philosophy. Oxford: Heineman Educational Publishers.

McCullough, M. E., \& Carter, E. C. (2013). Religion, Self-control and Self-regulation : How and Why are they related. APA Handbook of Psychology, Religion and Spirituality, Vol.1, 123-188.

McCullough, M. E., \& Willoughby, B. L. (2009). Religion, Self-Regulation, and Self-Control: Associations, Explanations, and Implications. Psychological Bulletin, Vol.135(1), 69 -93.

Messner, M. A. (2002). Taking the Field: Women, Men, and Sports. Minneapolis, MN: University of Minnesota Press.

Ngong, D. T. (2006). In Quest of Wholeness: African Christianity in the New Christianity. Review and Expositor, Vol.103, 519-540.

Ocha, W. (2013). Rethinking Gender: Negotiating Future Queer Rights in Thailand. Gender, Technology and Development, Vol. 17(1), 79-104.

Paloma, M. M. (2001). "The Pentecostal Movement". (S. Hunt, Ed.)

Prickett, P. J. (2015). Negotiating Gendered Religious Space: The Particularities of Patriarchy in an African American Mosque. Gender \& Society, Vol.29(1), 51-7.

Pollack, W. (2000). Real boys: Rescuing ourselves from the myths of boyhood. New York: Owl Books.

Sallee, M. W., \& Harris, F. (2011). Gender performance in qualitative studies of masculinities. Qualitative Research, 11(4), 409-429. doi: 10.1177/1468794111404322

Signoreilli, N. (1990). Children, Television, and Gender roles. Mesages and Impact. Journal of Adolscent Health Care, Vol. 11(1), 50-58.

Stephenson, L. P. (2011). Prophesying Women and Ruling Men: Women's Religious Authority in North American Pentecostalism. Religions, Vol.2, 410-426.

Stowers, S. (2007). The Concepts of 'Religion', 'Political Religion' and the Study of Nazism. Journal of Contemporary History, Vol. 42(1), 9-24.

Sullins, D. P. (2006). Gender and Religion: Deconstructing Universality, Constructing Complexity1. American Journal of Sociology, Vol.112(3), 838-80.

Sulmasy, D. P. (2002). A Biopsychosocial-Spiritual Model for the Care of Patients at the End of Life. The Gerontologist, Vol. 42( suppl 3), 24-33.

Tylor, E. B. (1981). Primitive culture: researches into the development of mythology, philosophy, religion, art, and custom (Vol. 2). J. Murray.

Ukah, A. (2007). African Christianities: Features, Promises and Problems (Working Papers). Universität Bayreuth, Germany. Retrieved from https://www.ifeas.uni-mainz.de/Dateien/AP79.pdf

Vanderstraeten, R. (2016). Parsons on Christianity. Thesis Eleven, Vol. 132(1), 50-61. doi:: $10.1177 / 0725513615619502$

Walter, T. (1990). Why Are Most Churchgoers Women? A Literature Review. Vox Evangelica, Vol.20, 73-90.

West, C., \& Zimmerman, H. D. (1987). Doing Gender. Gender \& Society, Vol.1(2), 125-151.

Wood, J. (2013). Gendered lives: Communication, Gender, and Culture (10th ed.). Wadsworth, Cengage Learining.

Woodhead, L. (2007). 'Real Religion and Fuzzy Sprituality. Questioning Some Deep Assumptions in the Sociology of Religion. In S. Aupers, \& D. Houtman, Religions of Modernity: Sacralising the Self and the Digital (forthcoming). 